\title{
A Study on Developmental History of Bilingual Education for Ethnic Koreans in China
}

\author{
Jin Junshu \\ Foreign Language School, Yanbian University, China \\ ¡injunshu@sina.com
}

Key words: bilingual education, developmental history, ethnic Koreans

\begin{abstract}
As a part of China's ethnic minority education, bilingual education for ethnic Koreans has greatly developed. This paper focuses on bilingual education for ethnic Koreans in China, and it firstly introduces the key concepts on bilingual education, in terms of its definitions, types and models; then overviews the developmental history of bilingual education for ethnic Koreans. This paper aims to provide some suggestions for improving the bilingual education for ethnic Koreans in China.
\end{abstract}

\section{Introduction}

Bilingual education is an important part of the ethnic minority education. With the rapid development of China's economy and society, the demand for the talents mastering Chinese and ethnic languages is further expanded, and the status and function of bilingual education become more and more important. Based on key concepts on bilingual education, including the definition, types and models of bilingual education, this paper focuses mainly on the developmental history of bilingual edcuation for ethnic Koreans in China, and aims to provide some suggestions to improve the teaching systems of ethnic Koreans in China.

\section{Key Concepts}

\subsection{Definition of Bilingual Education}

In discussing bilingual education among the minorities in China, the definition of bilingual education is needed to address first. The scholars and researchers at home and abroad defined bilingual education differently. The definition proposed by William (1987) is focused on in this paper, and bilingual education is defined as "an educational system that two languages are used in the process of education". Specifically speaking, "two languages" in bilingual education not only includes two languages are taught as subjects, but also refers to which language is used as the medium of instruction." This paper tries to explore bilingual education in a narrow sense, namely the bilingual education which the Korean and Chinese are used in instruction.

\subsection{Types of Bilingual Education}

China has 56 nationalities speaking over 80 languages, and most nationalities have their own native languages. The most typical type of bilingualism is the use of minority languages and Mandarin Chinese. However, different types can also be found. According to the findings of a national project of social sciences (Dai, 1996), bilingualism can be divided into major type such as Minority languages--Mandarin Chinese, and other types including Minority languages--minority languages and Mandarin Chinese--minority languages. Minority languages--Mandarin Chinese is the dominant type of bilingualism in China, and the bilingualism in ethnic Korean belongs to this type. To be more specific, the people in Yanbian area using mandarin Chinese together with their own language account for $20 \%--50 \%$ of the total population, while the rest $50 \%--80 \%$ use their own language. 


\subsection{Models of Bilingual Education}

Bilingual education in Chinese minority nationality regions may be of different types, which are determined by different factors, such as the settlement pattern, historical background, and characteristics of minority languages. The models of bilingual education could be classified into the following seven categories (An, 2007): regional models, syllabus models, models by dominant language in the classroom, models by school type, models by sequences, models by textbooks used, and models by the medium of instruction.

The model of bilingual education for ethnic Koreans belongs to regional models, from the perspective of region scope; and it begins in the primary school in terms of school type.

\section{The Bilingual Education Developmental History of Ethnic Koreans in China}

The ethnic minority education with a large scale, popularity and a sound education system began in 1949. The first higher education institution of the ethnic Koreans--Yanbian University was established in this year. From then on, the Education for ethnic Koreans in China has gone through 60 years, which can be divided into three stages according to its development (Yin, 2011).

\subsection{Rudimentary Stage of Bilingual Education for Ethnic Koreans in China (1949-1966)}

Ethnic Korean education has developed rapidly after the founding of People's Republic of China, which is mainly manifested in the following aspects:

1) Primary education has been greatly developed. Ethnic education has ushered in the historical period of rapid development, and has been in an unprecedented great development after the founding of the PRC. Private schools with "government support" were permitted in this period, and the primary and secondary education with Yanbian area as the center has a developed rapidly. According to the statistics in 1949 (Xuan, 1982), there were 622 Korean schools in Jilin province, including 576 private schools, accounting for $87 \%$, and more than 40 schools were Korean middle schools. The universal primary and secondary education were achieved in the Korean areas in 1952, and many senior high schools were set up in 1958. At his point, ethnic education system from primary schools to universities was set up and it entered into the trace of sound development.

2) Amateur education system was set up and many efforts were made to eliminate illiteracy. Affected by China's anti-Japanese War, many Korean young adults became illiterate or semiliterate. In order to eliminate illiteracy, the movement to eliminate illiteracy in Yanbian Korean Autonomous Prefecture was carried out in 1952. Various education institutions were established for adults and those who have not been educated received education. Illiteracy was basically eliminated in Yanbian area in 1958, and Yanbian Korean Autonomous Prefecture has become the first prefecture to eliminate illiteracy in China.

3) Vocational education system for fostering practical and application-oriented talents was set up. Besides full-time secondary schools and universities, a large number of vocational education institutions were set up to foster social talents after 1958. Some of these vocational schools provided the education of "part-work and part-study", and some provided the education of "part-agriculture and part-study". The practical problems were studied in class and the knowledge acquired in class was applied in practice, extraordinary results were achieved by learning and practice.

Overall, the teaching of Korean, Chinese and foreign language was attached great importance in ethnic Korean modern education. The development of bilingual education has been in its infancy.

\subsection{The Development Stage of Bilingual Education for Ethnic Koreans in China (1976-1990)}

Bilingual education can be divided into two stages according to its development process: the establishment of bilingual education goal and the experimental stage of bilingual education reform. 3.2.1 The establishment of bilingual education goal

Korean bilingual education vigorously developed in 1970s. Statistics shows that there were 312 
full-time Korean bilingual primary schools, the faculty in which includes 83857 students and 5681 teachers in Yanbian area in 1994. Besides, 77 full-time Korean bilingual junior high schools and 18 Korean bilingual senior high schools were set up, in which the numbers of students were 8827 and 7931 respectively. In addition, there were 18 vocational schools, a total of 8709 students; 21 technical schools, a total of 6273 students; and 11 secondary vocational schools for adults and workers, a total of 3133 students. These schools also include 5 universities, 656 kindergartens, 2 special schools with 442 students, 1128 adult technical schools, a total of 114947 students. These figures show that the Korean education has been greatly developed and ranked among the leading position of ethnic education.

\subsubsection{The experimental phase of bilingual education reform}

In 1988, Yanbian government put the "bilingual" education reform into an important agenda, and set up a special bilingual education research institute--Yanbian Ethnic Education Reform Office. From the beginning of the same year, overall reform on ethnic primary education focusing on "bilingual" education was carried out in more than 70 classes of 15 different schools. This experiment aims to master Korean and Chinese, combines the system, the curriculum, teaching materials, teaching methods, and teacher training on bilingual education together, and forms an optimized system in order to achieve the best effect. In 1993, bilingual teaching was implemented in Grade One in primary schools. The first round of experiment continued until the fall of 1994. Then the second round of experiment started, including the system and the curriculum on bilingual education, as well as some tests such as the Chinese Proficiency Test (HSK), Chinese Proficiency Test for Minorities in China (MHK) etc. In October 2002, the third round of experiment started, and it is the one of mastering three languages to achieve the goal of refining Korean, strengthening Chinese, optimizing foreign language. Through three rounds of experiments, the talent training mode was basically constructed, which aims to foster students' reading, writing, communication ability and other basic ability based on the bilingual teaching.

\subsubsection{The Enrichment Stage of Bilingual Education}

In twenty-first Century, bilingual education in Yanbian area was incorporated into the legal system with the deepening of the reform of bilingual education. After being approved by administrative departments of education in Yanbian area, some courses can be taught in Chinese. In addition, vocational schools and secondary specialized schools can be taught in Korean or Chinese. In the stage of primary

education, the teaching of Korean, Chinese and foreign language should be strengthened, so that students can master both Korean and Chinese, and lay the foundation to learn more languages.

In addition, government will provide special funds for preparing auto-visual materials for Korean bilingual schools, and set up information database for Korean teaching. In this way, the bilingual education will be guaranteed from the legal and financial support, which makes bilingual education develop in an orderly and healthy way.

\section{Conclusion}

As china has increasingly integrated into the world, bilingual education has become more and more important for China's education to face the world, the future, and modernization. This paper tries to provide some suggestions on bilingual education for ethnic Koreans, by identifing the definition, classification and model of bilingual education, and overviewing the developmental history of bilingual education among ethnic Koreans.

\section{References}

[1] Qing Xia Dai, Typology of Bilingualism and Bilingual Education in Chinese Minority Nationality Regions, Toronto: Multilingual Matters Ltd, pp. 78-80, 2007.

[2] Wei Feng An, Bilingual Education in China: Practices, Polices and Concepts Toronto: Multilingual Matters, pp. 83-85, 2007. 
[3] Yun Zhen Yin, "History and Present Problems in Education for Korean Minority in China with Countermeasures", Journal of Research on Education for Ethnic Minorities, vol. 01, pp. 67, 2011. 